\title{
Effects of Milk Replacer Composition on Growth, Body Composition, and Nutrient Excretion in Preweaned Holstein Heifers
}

\author{
S. R. Hill, ${ }^{\star}$ K. F. Knowlton, ${ }^{\star 1}$ K. M. Daniels, ${ }^{\star}$ R. E. James, ${ }^{\star}$ R. E. Pearson, ${ }^{\star}$ A. V. Capuco,† and R. M. Akers ${ }^{\star}$ \\ *Virginia Polytechnic Institute and State University, Blacksburg 24061 \\ †USDA-Agricultural Research Service, Beltsville, MD 20705
}

\begin{abstract}
Twenty-four newborn Holstein heifer calves were fed 1 of 4 milk replacers (MR): control (20\% CP, $21 \%$ fat; MR fed at $441 \mathrm{~g} / \mathrm{d}$ ); high protein/low fat (HPLF; 28\% CP, $20 \%$ fat; MR fed at $951 \mathrm{~g} / \mathrm{d}$ ); high protein/high fat (HPHF; 27\% CP, 28\% fat; MR fed at $951 \mathrm{~g} / \mathrm{d}$ ); and HPHF $\mathrm{MR}$ fed at a higher rate $(\mathrm{HPHF}+; 27 \% \mathrm{CP}, 28 \%$ fat; MR fed at $1,431 \mathrm{~g} / \mathrm{d})$. Dry calf starter $(20 \% \mathrm{CP}, 1.43 \%$ fat $)$ composed of ground corn (44.4\%), $48 \% \mathrm{CP}$ soybean meal (44.4\%), cottonseed hulls (11.2\%), and molasses (1.0\%) was offered free choice. Heifers were obtained from a commercial dairy, blocked by groups of 8 in the order acquired, and randomly assigned to treatments within group. Upon arrival at the research farm, heifers were fed the control for 2 feedings. Treatments were imposed when heifers were $4 \pm 1 \mathrm{~d}$ of age. Heifers were on study for $61 \pm 1 \mathrm{~d}$. Body weight and body size measures were taken weekly. Four-day total collection of feed refusals, feces, and urine was initiated at $57 \pm 1 \mathrm{~d}$ of age. Heifers were slaughtered at the end of the collection period to evaluate body composition. Preplanned contrasts were used to compare control to all, HPLF to HPHF, and $\mathrm{HPHF}$ to HPHF+. Heifers fed the control diet consumed more starter than those fed other treatment diets, but their total dry matter intake and apparent dry matter digestibility were lowest. Fecal output was highest in heifers fed the control diet, whereas urine output and urine $\mathrm{N}$ excretion were lowest. Nitrogen intake and urine $\mathrm{N}$ excretion were greater for heifers fed HPHF+ compared with HPHF but were not affected by MR fat content (HPLF vs. HPHF). Retention (g/d) of $\mathrm{N}$ and $\mathrm{P}$ was greater in heifers fed all nutrient-dense diets compared with those fed the control diet, but was not improved by increasing fat in the milk replacer (HPLF vs. HPHF) or by increasing the amount fed. Addition of fat to the milk replacer (HPLF vs. HPHF) increased empty body weight fat content without improving aver-
\end{abstract}

Received November 13, 2007.

Accepted April 18, 2008.

${ }^{1}$ Corresponding author: knowlton@vt.edu age daily gain or frame measures. Increasing the volume fed (HPHF vs. HPHF+) increased growth rate and empty body weight, but HPHF+ heifers were neither taller nor longer and their carcasses contained more fat. Clear improvements in growth and nutrient retention were observed with more nutrient-dense diets, but most of the improvements were seen with the increased protein intake relative to the control MR; adding fat to the high protein MR did not further improve lean tissue gain.

Key words: calf, milk replacer, nutrient excretion, body composition

\section{INTRODUCTION}

Practices for feeding young heifers have changed significantly in recent years for economic and environmental reasons. Heifers that grow faster reach puberty at a younger age and can become productive sooner. Tozer and Heinrichs (2001) estimated that reducing age at first calving by 1 mo decreases the cost of heifer rearing by $4.3 \%$. Feeding practices also have environmental implications. Approximately 4 to 4.5 million dairy heifer calves are born in the United States each year (Davis and Drackley, 1998), and the increasing animal density on farms and growth of the dairy heifer grower industry have spurred changes in concentrated animal feeding operation (CAFO) regulations to explicitly include calf growers and stand-alone heifer operations (EPA, 2003). Therefore, more data are needed to determine effects of changes in calf diets on excretion of manure, $\mathrm{N}$, and $\mathrm{P}$.

Altering milk replacer (MR) composition is one approach to accelerate gain, and much research has been published evaluating effects of varying MR protein and energy content (Jaster et al., 1992; Tikofsky et al., 2001; Blome et al., 2003; Bartlett et al., 2006; Bascom et al., 2007). Increased lean gain has been observed with increased MR protein content when energy was not limiting, and increased fat gain reported when protein was limiting (Tikofsky et al., 2001; Blome et al., 2003; Bartlett et al., 2006). Blome et al. (2003) fed Holstein heifers MR with 16.1, 18.5, 22.9, or 25.8\% CP and mea- 
sured linear increases in body weight gain, gain:feed ratio, absorbed N, and retained N. Bartlett et al. (2006) reported increased utilization efficiency of dietary protein and energy when feeding rate was increased, and Jaster et al. (1992) reported benefits with increasing fat intake to a total of about $200 \mathrm{~g} / \mathrm{d}$ but not at $350 \mathrm{~g} / \mathrm{d}$.

Data from these studies indicate the potential for altering the protein and energy content of the MR to improve efficiency of growth, but little work has been done to evaluate effects of increasing protein and fat content simultaneously. Also, few published data are available on the effect of diet on manure production and nutrient excretion by preweaned heifers. Our objective was to examine impacts on nutrient utilization and excretion when both protein and fat content were varied and when a high fat MR was fed at 2 different intakes.

\section{MATERIALS AND METHODS}

\section{Animals and Diets}

Twenty-four Holstein heifer calves were acquired from one commercial dairy farm within $3 \mathrm{~d}$ of birth $(40.4 \pm 2.2 \mathrm{~kg}$ of BW on arrival) and blocked into groups of 8 by the order acquired. Arrival dates for the 3 groups were August 20, September 10, and September 25, 2005. At the commercial dairy, all heifers received 1.89 $\mathrm{L}$ of thawed colostrum within $30 \mathrm{~min}$ of birth (via nipple bottle); colostrum was previously collected from multiparous dairy cows at the Virginia Tech Dairy Center (VTDC), pooled, and frozen in 1.89-L aliquots in plastic bags. Six to twelve hours after birth, all animals were fed a commercial colostrum replacement (Bovine IgG Colostrum Replacement, Land O'Lakes Inc. Animal Milk Products Co., Arden Hills, MN); $471 \mathrm{~g}$ was mixed into $1.89 \mathrm{~L}$ of 43 to $49^{\circ} \mathrm{C}$ water and fed by nipple bottle. All additional feedings at the commercial dairy consisted of twice-daily feedings ( $1.89 \mathrm{~L}$ ) of a $20 \% \mathrm{CP}, 21 \%$ fat MR (Land O'Lakes Inc. Animal Milk Products Co.) via nipple bottle; morning feedings were supplemented with $30 \mathrm{~g}$ of Gammulin (APC Inc., Ames, IA) mixed with MR. Immediately before and after travel to the VTDC, all heifers were offered $1.89 \mathrm{~L}$ of warm electrolytes (Travel-Lyte, Nouriche Nutrition Ltd., Lake St. Louis, MO).

Upon arrival at the VTDC, subcutaneous injections of $4 \mathrm{~mL}$ of Excenel (Pharmacia \& Upjohn Company, Kalamazoo, MI), $3 \mathrm{~mL}$ of BoSe (1 mg selenium and 68 $\mathrm{IU} / \mathrm{mL}$ of vitamin E; Schering-Plough Animal Health Corp., Union, $\mathrm{NJ}$ ), and $1 \mathrm{~mL}$ of vitamin $\mathrm{A}$ and $\mathrm{D}$ $(500,000 \mathrm{IU} / \mathrm{mL}$ of vitamin A, 75,000 IU/mL of vitamin D; Vedco Inc., St. Joseph, MO) were administered. Additionally, all animals received an intranasal dose of 2 $\mathrm{mL}$ of TSV-2 (Pfizer Animal Health, New York, NY; intranasal to prevent infectious bovine rhinotracheitis- parainfluenza type 3); at $9 \mathrm{~d}$ all animals received an intramuscular injection of $2 \mathrm{~mL}$ of Pyramid 5 (Fort Dodge Animal Health, Overland Park, KS, to prevent infectious bovine rhinotracheitis, bovine viral diarrhea, bovine viral syncytial virus, and parainfluenza 3 virus). One calf fed HPLF died at 6 wk of age (data removed from analysis) from acute peritonitis and endotoxemia. Just before slaughter, 2 heifers on HPHF+ showed symptoms of urinary tract infection, were treated with intravenous fluids and antibiotics, and survived until slaughter.

Upon arrival at VTDC, heifers were fed control for 2 feedings; treatments were imposed thereafter ( $4 \mathrm{~d} \pm 1$ $\mathrm{d}$ of age). The treatment diets were as follows: control (CON; 20\% CP, 21\% fat; MR fed at $441 \mathrm{~g} / \mathrm{d}$ ); high protein/low fat (HPLF, 28\% CP, 20\% fat; MR fed at 951 g/d); high protein/high fat (HPHF, 27\% CP, 28\% fat; MR fed at $951 \mathrm{~g} / \mathrm{d}$ ); and HPHF MR fed at a higher rate (HPHF+, 27\% CP, 28\% fat; MR fed at 1,431 g/d). All MR were prepared by Land O'Lakes Animal Products Co. were nonmedicated, contained whey protein as the protein source and animal tallow as the fat source, with proportions of these ingredients to produce varying contents of protein and fat. All MR were reconstituted to $12.5 \%$ solids. Heifers were fed MR twice daily at 0700 and $1900 \mathrm{~h}$ from nipple buckets.

Treatments were designed to compare the CON MR with the average of the other treatment diets; 2 isonitrogenous diets with 20 or $28 \%$ fat (HPLF vs. HPHF); and an extreme diet to evaluate the effects of more liberal intake (HPHF vs. HPHF+). The CON MR was fed at half the rate of the HPLF and HPHF to provide a control mimicking industry standard practice. These diets were formulated to support $0.55 / 0.57,0.98 / 1.30,1.06 / 1.23$, or $1.41 / 1.71 \mathrm{~kg} / \mathrm{d}$ of energy or protein allowable gain, respectively (NRC, 2001).

Fresh water and calf starter were available at all times. Starter was composed of ground corn (44.4\%), $48 \%$ CP soybean meal (44.4\%), cottonseed hulls (11.2\%), and molasses $(1.0 \%)$ and fed ad libitum to all heifers to prevent behavioral problems, allow normal gut development, and mimic typical industry conditions. Dry feed refusals were recorded daily at the evening feeding. Refusals of MR, if any, were recorded at each feeding.

Body weight, withers height (WH), body length (BL), hip width (HW), and hip height (HH) were measured weekly. Rectal temperatures were measured after arrival at VTDC to monitor heifer health. Data were not balanced by day and thus LS means were not estimable; however, arithmetic means within a normal range $\left(38.5^{\circ} \mathrm{C} \pm 0.15\right)$ indicate the heifers' good health status. Other measures of health were collected according to Daniels et al. (2008) and are reported therein. 


\section{Sample Collection and Preparation}

Total collection of feces, urine, and feed refusals were conducted for $4 \mathrm{~d}$ beginning on $\mathrm{d} 53$ of the study (heifers were $57 \mathrm{~d} \pm 1 \mathrm{~d}$ of age). Heifers were removed from hutches and placed in individual stalls $(30 \mathrm{~cm} \times 120$ $\mathrm{cm}$ ) in a 3 -sided naturally ventilated barn for total collection. Stall size, ambient temperature, and method of restraint in calf hutches and total collection stalls were similar. On the day calves were moved to the stalls, sterile Foley urethral catheters ( 8 French, $5 \mathrm{~mL}$, C. R. Bard Inc., Covington, GA) were placed for urine collection. Heifers were fitted with Velcro patches and bags to collect feces. Heifers were provided a 24 -h period for acclimation to the stalls and catheter after catheterization before the start of the 4-d total collection period. Every $6 \mathrm{~h}$, the total amount of urine was recorded and feces bags were removed, weighed, and stored in sealed 20 -L buckets. Feces bags were pooled by day ( 4 bags per bucket; 4 buckets per animal total). A $250-\mathrm{mL}$ sample of urine was collected at each 6 -h time point and acidified using $7.7 \mathrm{~mL}$ of $36 \mathrm{~N} \mathrm{H}_{2} \mathrm{SO}_{4} / \mathrm{kg}$ of urine. Urine samples were refrigerated and stored in closed containers for later analysis. At the end of each 24 -h period the feces bucket was weighed and a subsample of feces was collected. Feces samples were pooled (25\% of each daily sample) by calf across the collection period. Feces samples were dried in a forced air oven at $60^{\circ} \mathrm{C}$ for at least $48 \mathrm{~h}$ and weighed every $24 \mathrm{~h}$ until constant weight $( \pm 1$ g). Dried feces samples were ground through a 2-mm screen using a Wiley Mill (Arthur H. Thomas, Philadelphia, PA).

Blood samples were obtained twice weekly and analyzed for several hormones and blood metabolites. The collection methods and data results are reported in Daniels et al. (2008).

\section{Harvest Procedure}

All heifers were slaughtered at $65 \pm 1 \mathrm{~d}$ of age to evaluate body composition. Heifers were fasted for 12 $\mathrm{h}$ before slaughter and transported to the necropsy lab of the Virginia - Maryland Regional College of Veterinary Medicine for processing the morning of slaughter. Heifers were killed by phenobarbitol injection (Euthasol, $10 \mathrm{mg} / \mathrm{kg}$ of BW) and immediately exsanguinated. One heifer (group 3; CON) was suspected (at slaughter) to be a freemartin because of underdeveloped mammary tissue and a misshapen reproductive tract. Data from that calf were included in this manuscript.

Three body components were collected: blood and organs (BO); head, hide, feet, and tail (HHFT); and half of the carcass (HC). After exsanguination, blood was collected and the HHFT were removed and stored separately. All internal organs were removed and combined with the blood. Separate weights were collected for stomach (rumen + reticulum + omasum + abomasum; full and empty), empty small intestine, empty large intestine, liver, kidneys (untrimmed), and heart/trachea/lungs. A total weight was recorded for all blood and organs combined. The carcass was split longitudinally, weight of both sides recorded, and the left side retained for analysis. Final empty body weight (EBW) was calculated as the sum of the 3 components: carcass, HHFT, and BO. All components were refrigerated immediately after collection and frozen within $5 \mathrm{~h}$ of collection. Components were stored frozen for later analysis of composition.

Carcass components were transported frozen to the abattoir at the Beltsville Agricultural Research Center (Beltsville, MD) and ground through an Autio Gear Head Grinder (Model 801GH, Astoria, OR). The HHFT fraction was combined with the $\mathrm{BO}$ fraction to ensure proper grinding and to minimize loss of $\mathrm{BO}$ fraction during the grinding process. These 2 fractions were analyzed as one component (HHFT/BO). Components were ground 3 times; after the third grind, grab samples were obtained and frozen. Later, 100-g subsamples were taken of each component (HC and HHFT/BO) and freeze-dried (FreeZone Plus, Freeze Dry Systems, Labconco Corp, Kansas City, MO). Freeze-dried samples were ground through a 2-mm screen in a Wiley Mill (Arthur H. Thomas) with dry ice to prevent heating of the sample and loss of tissue.

\section{Sample Analysis}

Urine and feces were analyzed for total Kjeldahl N and total P (AOAC, 1984). Samples of MR, calf starter, and body tissue (HHFT/BO and HC) were analyzed for DM, total Kjeldahl N, total P (AOAC, 1984), total fat by supercritical fluid extraction (TFE2000 Leco Fat Extractor, St. Joseph, MI), and gross energy by bomb calorimetry (Parr 1271 Automatic Bomb Calorimeter, Parr Instrument Company, Moline, IL).

\section{Statistical Analysis}

Digestibility, nutrient partitioning, and body composition data were analyzed using the GLM procedure of SAS (SAS Institute, 1999). Growth and intake data were analyzed using the MIXED procedure of SAS with repeated measures. The repeated measure was week, and the subject used in tests was heifer within treatment and group. A compound symmetry covariance structure was used. A test of power was completed before the study to ensure that replication was adequate to detect relationships. Effects of treatment, group, heifer, and the interaction of treatment and group with repeated week were represented by the model: 
Table 1. Ingredient and nutrient composition of starter and milk replacers varying in protein and fat fed to Holstein heifer calves

\begin{tabular}{lcccr}
\hline & \multicolumn{3}{c}{ Dietary treatment $^{1}$} \\
\cline { 2 - 4 } Item & CON & HPLF & HPHF & HPHF+ \\
\hline Milk replacer & & & & 27.1 \\
CP, \% of DM & 19.8 & 28.3 & 27.6 & 27.6 \\
Fat, \% of DM & 21.1 & 19.8 & 5.24 & 0.74 \\
Gross energy, Mcal/kg & 4.69 & 4.90 & 0.74 & 1,431 \\
P, \% of DM & 0.84 & 0.85 & & \\
Powder, g of DM/d & 441 & 951 & & \\
Starter ingredient, \% of diet DM & & & & \\
Corn grain, ground & 44.4 & & & \\
Soybean meal & 44.4 & & & \\
Cottonseed hulls & 11.2 & & & \\
Dried molasses & 1.0 & & & \\
Starter composition & & & \\
CP, \% of DM & 20.3 & & \\
P, \% of DM & 0.72 & & & \\
Fat, \% of DM & 1.43 & & & \\
Gross energy, Mcal/kg & 3.52 & & & \\
\hline
\end{tabular}

${ }^{1} \mathrm{CON}=$ milk replacer with $20 \% \mathrm{CP}$ and $21 \%$ fat, fed at $441 \mathrm{~g}$ of DM/d; HPLF $=$ milk replacer with $28 \%$ $\mathrm{CP}$ and $20 \%$ fat, fed at $951 \mathrm{~g}$ of $\mathrm{DM} / \mathrm{d}$; $\mathrm{HPHF}=$ milk replacer with $27 \% \mathrm{CP}$ and $28 \%$ fat, fed at $951 \mathrm{~g}$ of $\mathrm{DM} / \mathrm{d}$; and $\mathrm{HPHF}+=$ milk replacer with $27 \% \mathrm{CP}$ and $28 \%$ fat fed at $1,431 \mathrm{~g}$ of DM/d.

$$
\mathrm{Y}=\mu+\mathrm{T}_{\mathrm{i}}+\mathrm{G}_{\mathrm{j}}+\mathrm{TG}_{(\mathrm{ij})}+\mathrm{H}_{(\mathrm{ij}) \mathrm{k}}+\mathrm{W}_{\mathrm{l}}+\mathrm{E}_{\mathrm{ijkl}},
$$

where $\mu=$ overall population mean; $T_{i}=$ fixed effect of the ith diet $(\mathrm{i}=1,2,3,4) ; \mathrm{G}_{\mathrm{j}}=$ fixed effect of $\mathrm{jth}$ group $(\mathrm{j}=1,2,3) ; \mathrm{TG}_{(\mathrm{ij})}=$ fixed interaction of diet and group; and $\mathrm{H}_{(\mathrm{ij}) \mathrm{k}}=$ random effect of heifer within treatment and group; $\mathrm{W}_{\mathrm{l}}=$ fixed effect of lth week $(\mathrm{l}=1,2,3 \ldots 9)$; and $\mathrm{E}_{\mathrm{ijkl}}=$ residual error term (assumed to be random and independently distributed).

Initial body measures (BW, WH, BL, $\mathrm{HH}$, and $\mathrm{HW}$ ) were used as a covariate in analysis of final body measures. Preplanned contrasts were used to compare CON to all other treatments, HPLF to HPHF, and HPHF to $\mathrm{HPHF}+$. Because the planned contrasts were not orthogonal, means were tested with the Bonferroni method. Data are reported as least squares means and differences were declared significant at $P<0.05$. Trends were declared at $P<0.10$.

\section{RESULTS AND DISCUSSION}

\section{Diet Composition and Nutrient Intake}

Ingredient and nutrient composition of $\mathrm{MR}$ and starter are listed in Table 1. Amount of MR fed each day was fixed within treatment and with few exceptions, heifers consumed all MR offered (Table 2) within 30 min of feeding. In the first week of the study, some heifers fed HPHF+ did not consume all MR within 30 $\mathrm{min}$. For those heifers, refusals were weighed $30 \mathrm{~min}$ after feeding. That quantity of MR was mixed fresh and offered at $1200 \mathrm{~h}$, and all was consumed. After $7 \mathrm{~d}$ of age, no MR was refused at any feeding. Because amount of MR consumed was fixed within treatment, no variation could be detected in intake of MR and MR nutrients and no error term existed for testing.

Intake of calf starter and total DM intake increased across the study (Figures 1a, 1b). Interestingly, the treatment by week interaction was significant for intake of calf starter and total DM. Heifers fed CON and HPLF increased intake markedly, whereas intakes of heifers fed the high fat diets (HPHF, HPHF+) changed little across the duration of the study. Groups differed in total DMI, but the significant treatment $\times$ group interaction $(P<0.01)$ complicates interpretation. Calves arriving in the first and second groups (August 20 and September 10) and fed HPHF consumed less calf starter than HPLF and HPHF+. This was not true in the group that arrived September 25. The biological explanation for this interaction is not apparent.

Across the study, heifers fed CON consumed more starter (571 vs. $350 \mathrm{~g} / \mathrm{d}$ average of other treatments; Table 2) and therefore more nutrients from starter than other heifers. They consumed less total DM, and intake of all nutrients (N, P, fat, energy) was lowest in $\mathrm{CON}$ heifers throughout the study (Table 2).

Starter DM intake was not affected by the addition of fat to the high protein MR diets (HPLF vs. HPHF; Table 2) although total fat intake increased as expected (198 vs. $248 \mathrm{~g}$ of fat/d; $P<0.01$ ). Intake of total $\mathrm{N}$ tended to be lower in calves fed HPHF as compared with HPLF and $\mathrm{P}$ intake was less. These changes were due to the slightly lower $\mathrm{N}$ and $\mathrm{P}$ content of the HPHF MR as compared with HPLF and the numerical (not significant) reduction in starter intake. 
Table 2. Nutrient intake ${ }^{1}$ in Holstein heifer calves fed milk replacers varying in protein and fat

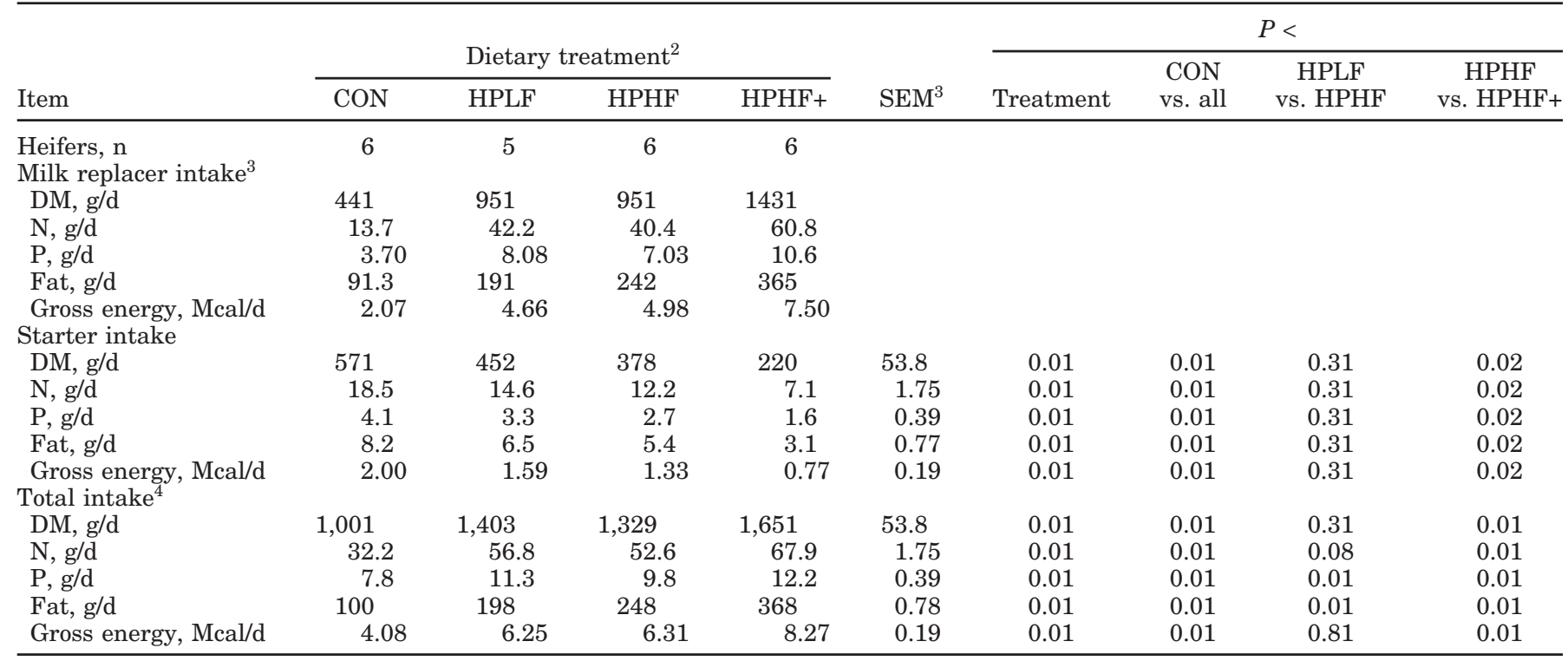

${ }^{1}$ Overall least squares means from $61 \mathrm{~d}$ study.

${ }^{2} \mathrm{CON}=$ milk replacer with $20 \% \mathrm{CP}$ and $21 \%$ fat, fed at $441 \mathrm{~g}$ of DM/d; HPLF = milk replacer with $28 \% \mathrm{CP}$ and $20 \%$ fat, fed at $951 \mathrm{~g}$ of $\mathrm{DM} / \mathrm{d}$; HPHF = milk replacer with $27 \% \mathrm{CP}$ and $28 \%$ fat, fed at $951 \mathrm{~g}$ of DM/d; and HPHF+ = milk replacer with $27 \% \mathrm{CP}$ and $28 \%$ fat fed at $1,431 \mathrm{~g}$ of $\mathrm{DM} / \mathrm{d}$.

${ }^{3}$ No statistical analysis was completed because within treatment, equal amounts were fed daily and probability of difference could not be calculated.

${ }^{4}$ Total intake $=$ starter plus milk replacer.

Starter intake decreased (378 vs. $220 \mathrm{~g} / \mathrm{d}$ ) when MR volume was increased (HPHF vs. HPHF+; Table 2; $P$ $<0.02$ ). Total DMI was greater in $\mathrm{HPHF}+$ than in HPHF (1,651 vs. $1,329 \mathrm{~g} / \mathrm{d}$; Table 2 ) because of increased MR intake. Intake of $\mathrm{N}, \mathrm{P}$, fat, and energy increased with an increase in volume of MR fed. Reduced starter intake in heifers on this study fed more nutrient-dense diets was likely due to a combination of increased MR consumption and increased fat content of the MR. Jaster et al. (1992) observed no effect on starter intake when fat intake was increased from control $(\sim 105 \mathrm{~g} / \mathrm{d})$ to 259 $\mathrm{g} / \mathrm{d}$, but did observe a decrease in starter intake in 4 week old heifers when fat was fed at $\sim 350 \mathrm{~g} / \mathrm{d}$. In addition, Jaster et al. (1992) observed depression in grain intake with increased feeding rate and reconstitution of MR to greater solids content.

\section{Body Weight and Growth Measures}

Initial BW tended to be different $(P<0.09$; Table 3 ; Figure 2) among diets. Heifers fed HPLF were bigger than those fed HPHF. This was not intentional, and its possible effects on study results are discussed below. Initial $\mathrm{WH}, \mathrm{BL}, \mathrm{HH}$, and $\mathrm{HW}$ were similar among all heifers. As expected, heifers fed $\mathrm{CON}$ had the smallest final BW and the smallest WH, BL, HH, and HW. Average daily gain was lower in heifers fed CON compared with the other treatments. Similarly, Bartlett et al. (2006) observed lower ADG in calves fed MR with less than $22 \% \mathrm{CP}$, and Blome et al. (2003) reported increased ADG with increasing MR protein content.

Calves fed additional fat (HPLF vs. HPHF) had decreased final BW, final HW, and tended to be smaller at the withers (WH), but the magnitude of the differences in final body size between HPLF and HPHF heifers was similar to differences between these treatment groups at the start of the study. Resulting ADG was similar among heifers fed these 2 diets. Results for these measures indicate that adding fat to the MR without increasing protein did not improve overall growth.

Increasing the volume fed increased final BW and greater ADG compared with heifers fed HPHF, but did not affect any other measures of body size (Table 3). This could indicate that as BW increased, heifers were gaining fat and potentially muscle, but not increasing frame growth. Body composition data (discussed below) confirm this trend.

Gain to feed ratio was lower $(0.36$ vs. $0.44 ; P<0.05)$ in heifers fed CON compared with the average of those fed the other diets, but the overall effect of treatment was not significant. Given the increased starter intake and low DM digestibility in heifers fed CON, less efficient gain was expected when compared with heifers consuming mainly liquid feed. Feed efficiency was not 

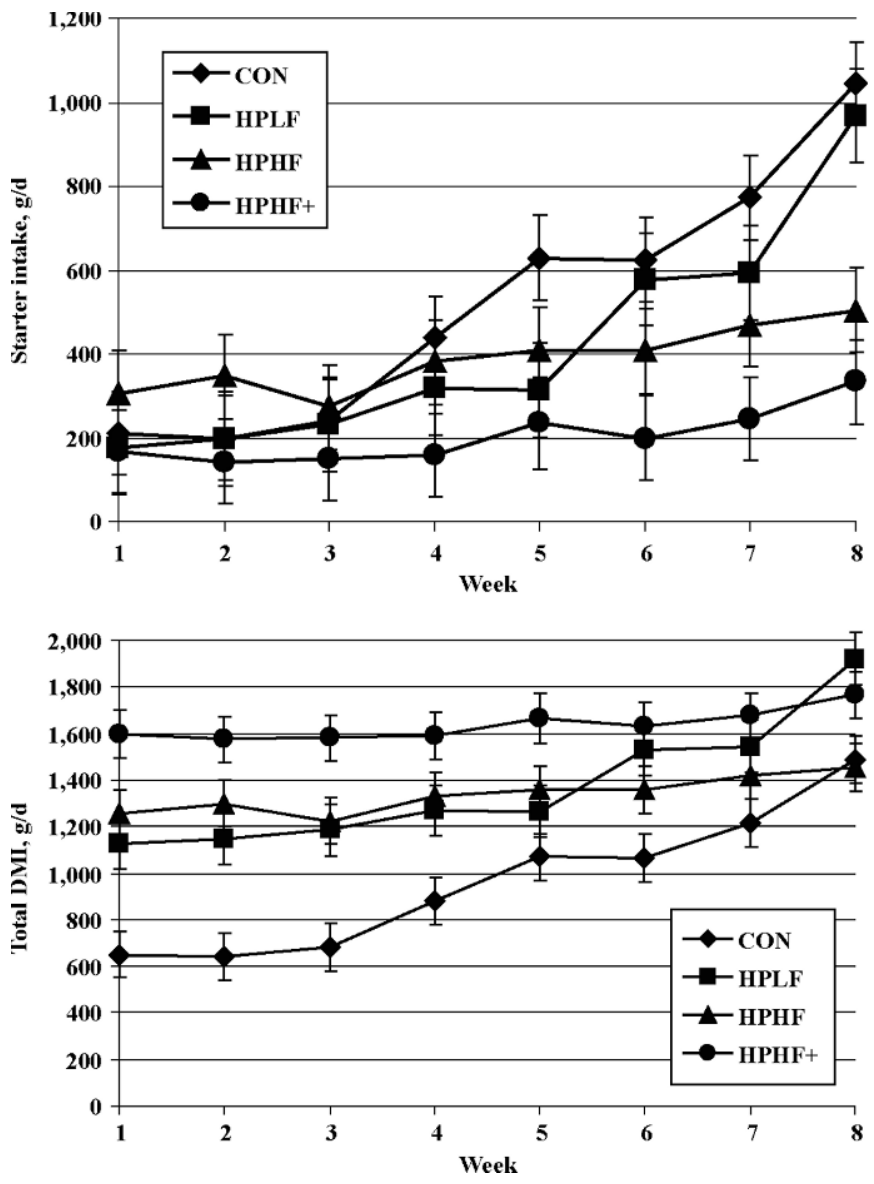

Figure 1. Starter intake in Holstein heifer calves fed milk replacers varying in protein and fat (upper). Total DMI in Holstein heifer calves fed milk replacers varying in protein and fat (lower). $\mathrm{CON}=$ milk replacer with $20 \% \mathrm{CP}$ and $21 \%$ fat, fed at $441 \mathrm{~g}$ of DM/ $\mathrm{d}$; HPLF $=$ milk replacer with $28 \% \mathrm{CP}$ and $20 \%$ fat, fed at $951 \mathrm{~g}$ of $\mathrm{DM} / \mathrm{d} ; \mathrm{HPHF}=$ milk replacer with $27 \% \mathrm{CP}$ and $28 \%$ fat, fed at 951 $\mathrm{g}$ of $\mathrm{DM} / \mathrm{d} ; \mathrm{HPHF}+=$ milk replacer with $27 \% \mathrm{CP}$ and $28 \%$ fat fed at $1,431 \mathrm{~g}$ of $\mathrm{DM} / \mathrm{d}$.

improved with additional fat or with increased feeding rate. The latter result is contradictory to the observations of Bartlett et al. (2006) of more efficient gain with increased feeding rate (1.25 to $1.75 \%$ of BW). Feeding rates in the current study were $1.61 \%$ of BW for HPHF and $2.12 \%$ of $\mathrm{BW}$ for $\mathrm{HPHF}+$. Feed to gain ratios in this study were low compared with those of Diaz et al. (2001), Blome et al. (2003), and Bartlett et al. (2006) because calf starter (with a lower digestibility than a liquid diet) was not offered in those studies and was fed ad libitum in our study.

\section{Organ Weights}

Both full and empty stomachs of heifers fed CON were heavier than those of heifers fed more nutrientdense diets (Table 4). There was no difference in the weights of the small intestine in calves fed CON or in the weights of the large intestine as a percentage of EBW. In contrast, the large intestine of CON heifers tended to be smaller than in other calves on an absolute (g) basis. On an absolute basis the liver and combined trachea, heart, and lungs were smaller in heifers fed CON. However, size differences in these organs were proportional to the smaller body size of these heifers, as the effect of CON disappears when data are expressed per unit of EBW (Table 4). Blome et al. (2003) noted kidney weight increased quadratically with dietary protein; greatest values were observed in heifers fed a $22.9 \%$ protein MR.

Empty stomachs were smaller (absolute and relative to EBW) in heifers fed HPHF than in those fed HPLF (Table 4) and kidneys were smaller as well (absolute). The explanation for these changes is not obvious; $\mathrm{N}$ intake and $\mathrm{P}$ intake were slightly lower in HPHF calves (Table 2) but the magnitude of those differences was small. No differences were observed in weight of digestive organs (stomach, intestines) between heifers fed greater volume of MR (HPHF+) compared with HPHF. The trachea, heart and lungs were a smaller proportion of body weight and the livers $(P<0.07)$ and kidneys $(P<0.09)$ tended to be larger in heifers fed HPHF+ compared with HPHF. Bartlett et al. (2006) observed increasing weights of the gastrointestinal tract, liver, heart, and kidneys in heifers fed at $1.75 \%$ of $\mathrm{BW}$ as compared with those fed at $1.25 \% \mathrm{BW}$.

Total viscera weight was calculated as the sum of rumen, small intestine, large intestine, heart, lungs, trachea, liver, kidney, and spleen weights. Pancreas weight was not recorded and kidney weights are missing from 2 calves (both fed $\mathrm{HPHF}+$ ). These missing values may have affected treatment outcomes.

Total viscera weight tended to be lower in heifers fed CON (Table 4; $P<0.08$ ), but because of their smaller body size, total viscera was greater as a percentage of EBW. The addition of fat to the MR did not change total viscera weight on an absolute or relative basis. Increasing the volume fed increased total viscera weight on an absolute basis, but because of greater body size in heifers fed $\mathrm{HPHF}+$, total viscera as a percentage of EBW was smaller when compared with HPHF (10.2 vs. $15.3 \%$ EBW, $P<0.02)$. Similarly, Bartlett et al. (2006) observed greater total viscera weight with increased feeding rate but no effect of MR protein content (14 to 26\%). Blome et al. (2003) observed that total viscera weight increased linearly with increased protein in the MR.

\section{Body Components and Chemical Composition}

Body nutrient weights ( $\mathrm{kg}$ of $\mathrm{CP}$, fat, and ash) summed to $\sim 95 \%$ of dry EBW; the loss was probably 
Table 3. Growth measures in Holstein heifer calves fed milk replacers varying in fat and protein content

\begin{tabular}{|c|c|c|c|c|c|c|c|c|c|}
\hline \multirow[b]{3}{*}{ Item } & \multirow{2}{*}{\multicolumn{4}{|c|}{ Dietary treatment ${ }^{1}$}} & \multirow[b]{3}{*}{ SEM } & \multicolumn{4}{|c|}{$P<$} \\
\hline & & & & & & \multirow[b]{2}{*}{ Treatment } & \multirow{2}{*}{$\begin{array}{c}\text { CON } \\
\text { vs. all }\end{array}$} & \multirow{2}{*}{$\begin{array}{c}\text { HPLF } \\
\text { vs. HPHF }\end{array}$} & \multirow{2}{*}{$\begin{array}{c}\text { HPHF } \\
\text { vs. } \mathrm{HPHF}+\end{array}$} \\
\hline & $\mathrm{CON}$ & HPLF & $\mathrm{HPHF}$ & $\mathrm{HPHF}+$ & & & & & \\
\hline \multicolumn{10}{|l|}{ Initial body measure } \\
\hline BW, kg & 41.1 & 45.8 & 36.3 & 40.1 & 2.53 & 0.09 & 0.88 & 0.02 & 0.25 \\
\hline Wither height, $\mathrm{cm}$ & 82.7 & 87.2 & 83.0 & 79.0 & 2.68 & 0.20 & 0.92 & 0.26 & 0.25 \\
\hline Body length, cm & 70.5 & 72.4 & 67.9 & 70.9 & 2.02 & 0.42 & 0.97 & 0.12 & 0.26 \\
\hline \multicolumn{10}{|l|}{ Final body measure } \\
\hline $\mathrm{BW}, \mathrm{kg}$ & 66.4 & 86.8 & 76.0 & 91.6 & 2.85 & 0.01 & 0.01 & 0.02 & 0.01 \\
\hline Wither height, cm & 86.4 & 94.2 & 90.4 & 93.1 & 1.60 & 0.01 & 0.01 & 0.10 & 0.19 \\
\hline Body length, cm & 82.3 & 91.0 & 87.4 & 90.6 & 1.43 & 0.01 & 0.01 & 0.12 & 0.14 \\
\hline Hip height, cm & 89.3 & 98.2 & 93.6 & 93.7 & 2.30 & 0.09 & 0.03 & 0.15 & 0.94 \\
\hline Hip width, cm & 24.3 & 30.7 & 27.3 & 28.8 & 1.09 & 0.01 & 0.01 & 0.04 & 0.29 \\
\hline Average daily gain, g/d & 368 & 610 & 566 & 736 & 5.12 & 0.01 & 0.01 & 0.54 & 0.03 \\
\hline
\end{tabular}

${ }^{1} \mathrm{CON}=$ milk replacer with $20 \% \mathrm{CP}$ and $21 \%$ fat, fed at $441 \mathrm{~g}$ of DM/d; HPLF = milk replacer with $28 \% \mathrm{CP}$ and $20 \%$ fat, fed at $951 \mathrm{~g}$ of $\mathrm{DM} / \mathrm{d} ; \mathrm{HPHF}=$ milk replacer with $27 \% \mathrm{CP}$ and $28 \%$ fat, fed at $951 \mathrm{~g}$ of DM/d; and HPHF+ = milk replacer with $27 \% \mathrm{CP}$ and $28 \%$ fat fed at $1,431 \mathrm{~g}$ of $\mathrm{DM} / \mathrm{d}$.

due to errors in sampling and analysis. This recovery is similar to that observed by Bascom et al. (2007).

Heifers fed CON had lower EBW compared with those fed other MR (58.7 vs. $79.3 \mathrm{~kg}$; Table 5) and weight of water, CP, fat, ash, and energy in the body were lower in heifers fed CON as well (Table 5). Protein and ash content (\% of EBW) were greater in CON calves as was body $\mathrm{P}$ content, and body fat was a correspondingly smaller portion of EBW. Energy concentration in the EBW was lower in calves fed CON than in calves fed other MR (4.86 vs. $5.32 \mathrm{Mcal} / \mathrm{kg}$ of EBW DM; $P<0.01$ ).

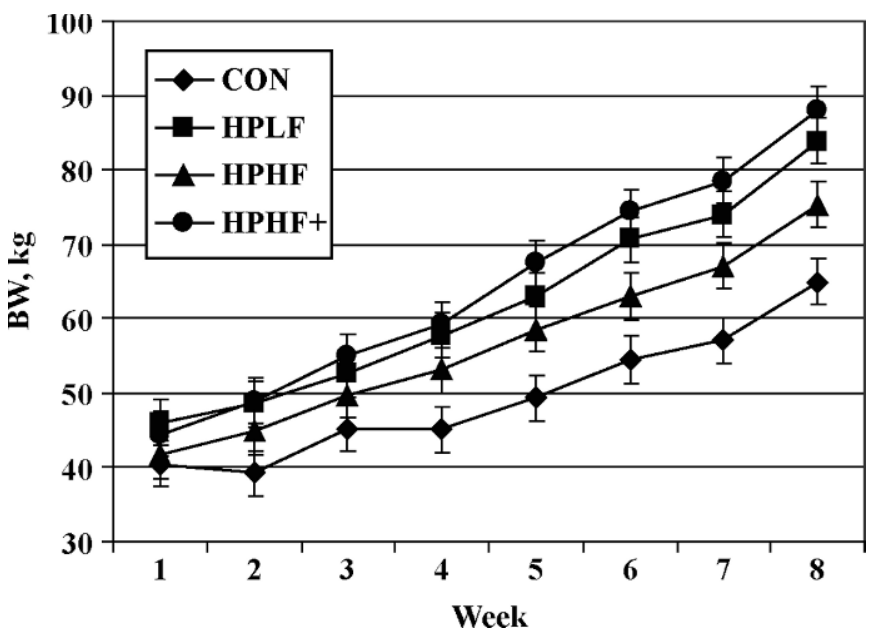

Figure 2. Body weight $(\mathrm{kg})$ in Holstein heifer calves fed milk replacers varying in protein and fat. CON $=$ milk replacer with $20 \%$ $\mathrm{CP}$ and $21 \%$ fat, fed at $441 \mathrm{~g}$ of $\mathrm{DM} / \mathrm{d}$; $\mathrm{HPLF}=$ milk replacer with $28 \% \mathrm{CP}$ and $20 \%$ fat, fed at $951 \mathrm{~g}$ of $\mathrm{DM} / \mathrm{d} ; \mathrm{HPHF}=$ milk replacer with $27 \% \mathrm{CP}$ and $28 \%$ fat, fed at $951 \mathrm{~g}$ of DM/d; HPHF+ = milk replacer with $27 \% \mathrm{CP}$ and $28 \%$ fat fed at $1,431 \mathrm{~g}$ of DM/d.
Heifers fed additional fat (HPHF) tended to have smaller EBW (kg wet) than those fed HPLF; the difference was accounted for by reduced carcass water $(P<$ $0.08)$, protein $(P<0.01)$, and ash $(P<0.01)$ weights. The lower wet EBW in HPHF heifers reflected their smaller initial and final live body weight, but the decrease in body protein and ash are also apparent when expressed as a proportion of EBW. The HPHF calves also had relatively more fat (23.8 vs. $19.3 \%)$ and energy (5.36 vs. $5.05 \mathrm{Mcal} / \mathrm{kg}$ of EBW DM) than calves fed HPLF. This increase in relative fat content explains the reduction in body water because adipose tissue contains less water than muscle tissue. Similarly, Tikofsky et al. (2001) observed increased carcass fat content with increasing fat in the MR from 23.5 to 24.8 or $27.0 \%$ fat.

Bartlett et al. (2006) reported similar results; as fat in the MR increased from $18 \%$ to $23 \%$ and protein decreased from 26 to $14 \%$, protein in the body decreased and fat increased. Interestingly, the MR fed by Bartlett et al. (2006) were isocaloric despite their differing fat content. This suggests that total fat supply in the MR may be more important than energy supplied. Blome et al. (2003) fed isocaloric MR and increased the MR protein content from $16 \%$ to $26 \%$ and noted an increase in body protein. Together, these reports and the research reported herein suggest that feeding a MR above $21 \%$ fat is not beneficial as long as energy supply is adequate.

Heifers consuming increased volume of MR (HPHF+ vs. HPHF; $2.12 \%$ of BW vs. $1.61 \%$ of BW) had greater EBW and greater weights of all nutrients (water, CP, $\mathrm{P}$, fat, ash) than heifers fed HPHF (Table 5). Bartlett et al. (2006) also observed an increase in EBW, water, 
Table 4. Weight of organs in Holstein heifer calves fed milk replacers varying in fat and protein content

\begin{tabular}{|c|c|c|c|c|c|c|c|c|c|}
\hline \multirow[b]{3}{*}{ Item } & \multirow{2}{*}{\multicolumn{4}{|c|}{ Dietary treatment $^{1}$}} & \multirow[b]{3}{*}{ SEM } & \multicolumn{4}{|c|}{$P<$} \\
\hline & & & & & & \multirow[b]{2}{*}{ Treatment } & \multirow{2}{*}{$\begin{array}{c}\text { CON } \\
\text { vs. all }\end{array}$} & \multirow{2}{*}{$\begin{array}{c}\text { HPLF } \\
\text { vs. HPHF }\end{array}$} & \multirow{2}{*}{$\begin{array}{c}\text { HPHF } \\
\text { vs. } \mathrm{HPHF}+\end{array}$} \\
\hline & $\mathrm{CON}$ & HPLF & HPHF & $\mathrm{HPHF}+$ & & & & & \\
\hline Full stomach, $\mathrm{g}$ & 5,858 & 3,850 & 2,558 & 3,167 & 874 & 0.08 & 0.02 & 0.33 & 0.64 \\
\hline$\% \mathrm{EBW}^{2}$ & 10.1 & 4.80 & 3.57 & 3.55 & 1.34 & 0.02 & 0.01 & 0.54 & 1.0 \\
\hline Empty stomach, g & 1,275 & 1,317 & 717 & 808 & 118 & 0.01 & 0.02 & 0.01 & 0.50 \\
\hline$\%$ EBW & 2.15 & 1.62 & 1.01 & 0.94 & 0.15 & 0.01 & 0.01 & 0.02 & 0.69 \\
\hline Large intestine, $\mathrm{g}^{3}$ & 775 & 925 & 1,625 & 2,190 & 418 & 0.10 & 0.10 & 0.23 & 0.29 \\
\hline$\%$ EBW & 1.28 & 1.17 & 2.26 & 2.36 & 0.54 & 0.26 & 0.29 & 0.16 & 0.88 \\
\hline Trachea + heart + lungs, $\mathrm{g}$ & 1,808 & 2,192 & 2,217 & 2,400 & 132 & 0.03 & 0.01 & 0.89 & 0.29 \\
\hline$\%$ EBW & 3.10 & 2.78 & 3.16 & 2.78 & 0.14 & 0.09 & 0.18 & 0.06 & 0.04 \\
\hline Liver, $\mathrm{g}$ & 1,527 & 1,847 & 1,933 & 2,387 & 167 & 0.03 & 0.02 & 0.71 & 0.07 \\
\hline$\% \mathrm{EBW}$ & 2.64 & 2.33 & 2.74 & 2.69 & 0.22 & 0.55 & 0.81 & 0.20 & 0.87 \\
\hline Kidneys, untrimmed, $\mathrm{g}$ & 1,950 & 2,258 & 1,593 & 2,235 & 280 & 0.12 & 0.55 & 0.03 & 0.09 \\
\hline
\end{tabular}

${ }^{1} \mathrm{CON}=$ milk replacer with $20 \% \mathrm{CP}$ and $21 \%$ fat, fed at $441 \mathrm{~g}$ of DM/d; HPLF = milk replacer with $28 \% \mathrm{CP}$ and $20 \%$ fat, fed at $951 \mathrm{~g}$ of $\mathrm{DM} / \mathrm{d} ; \mathrm{HPHF}=$ milk replacer with $27 \% \mathrm{CP}$ and $28 \%$ fat, fed at $951 \mathrm{~g}$ of DM/d; and HPHF+ = milk replacer with $27 \% \mathrm{CP}$ and $28 \%$ fat fed at $1,431 \mathrm{~g}$ of $\mathrm{DM} / \mathrm{d}$.

${ }^{2} \mathrm{EBW}=$ empty body weight.

${ }^{3}$ Weights of small and large intestine are empty weights.

protein, fat, and ash as feeding rate was increased. Heifers fed HPHF+ had relatively more fat in their carcasses than heifers fed HPHF (27.0 vs. $23.8 \%$ of EBW-dry basis; Table 5) and tended to have greater body energy content (5.56 vs. $5.36 \mathrm{Mcal} / \mathrm{kg}$ of EBW DM; $P<0.08)$. Similarly, Bartlett et al. (2006) reported an increase in body fat when feeding rate was increased from 1.25 to $1.75 \%$ of BW.

\section{Digestibility Trial}

Data reported from the digestibility trial (Tables 6 to 8) represent the 4-d total collection period commencing on $\mathrm{d} 53$ of the study.

Dry Matter Intake and Manure Excretion. During the collection period, CON heifers had the lowest DM digestibility (62.0 vs. $78.8 \%$; Table 6 ) and tended

Table 5. Empty body composition of Holstein heifer calves fed milk replacers varying in protein and fat

\begin{tabular}{|c|c|c|c|c|c|c|c|c|c|}
\hline \multirow[b]{3}{*}{ Item } & \multirow{2}{*}{\multicolumn{4}{|c|}{ Dietary treatment $^{1}$}} & \multirow[b]{3}{*}{ SEM } & \multicolumn{4}{|c|}{$P<$} \\
\hline & & & & & & \multirow[b]{2}{*}{ Treatment } & \multirow{2}{*}{$\begin{array}{c}\text { CON } \\
\text { vs. all }\end{array}$} & \multirow{2}{*}{$\begin{array}{c}\text { HPLF } \\
\text { vs. HPHF }\end{array}$} & \multirow{2}{*}{$\begin{array}{c}\text { HPHF } \\
\text { vs. HPHF+ }\end{array}$} \\
\hline & $\mathrm{CON}$ & HPLF & HPHF & $\mathrm{HPHF}+$ & & & & & \\
\hline $\mathrm{EBW},{ }^{2} \mathrm{~kg}$ & 58.7 & 79.3 & 70.4 & 88.2 & 3.21 & 0.01 & 0.01 & 0.07 & 0.01 \\
\hline EBW, $\mathrm{kg}$ of DM & 17.6 & 25.8 & 23.3 & 29.6 & 1.15 & 0.01 & 0.01 & 0.13 & 0.01 \\
\hline \multicolumn{10}{|l|}{ Component, $\mathrm{kg}$} \\
\hline Water & 41.1 & 53.5 & 47.1 & 58.6 & 2.49 & 0.01 & 0.01 & 0.08 & 0.01 \\
\hline Ash & 2.98 & 4.02 & 3.26 & 3.78 & 0.16 & 0.01 & 0.01 & 0.01 & 0.03 \\
\hline $\mathrm{P}$ & 0.33 & 0.37 & 0.29 & 0.45 & 0.05 & 0.12 & 0.47 & 0.24 & 0.03 \\
\hline Gross energy, Mcal & 85.6 & 130.1 & 124.8 & 166.0 & 7.86 & 0.01 & 0.01 & 0.63 & 0.01 \\
\hline \multicolumn{10}{|c|}{ Empty body composition (DM basis) } \\
\hline $\mathrm{CP}, \%$ & 61.8 & 60.6 & 56.0 & 54.3 & 0.69 & 0.01 & 0.01 & 0.01 & 0.11 \\
\hline Fat, \% & 16.7 & 19.3 & 23.8 & 27.0 & 0.87 & 0.01 & 0.01 & 0.01 & 0.02 \\
\hline Ash, \% & 16.9 & 15.6 & 14.0 & 12.9 & 0.54 & 0.01 & 0.01 & 0.06 & 0.12 \\
\hline
\end{tabular}

${ }^{1} \mathrm{CON}=$ milk replacer with $20 \% \mathrm{CP}$ and $21 \%$ fat, fed at $441 \mathrm{~g}$ of DM/d; HPLF = milk replacer with $28 \% \mathrm{CP}$ and $20 \%$ fat, fed at $951 \mathrm{~g}$ of $\mathrm{DM} / \mathrm{d} ; \mathrm{HPHF}=$ milk replacer with $27 \% \mathrm{CP}$ and $28 \%$ fat, fed at $951 \mathrm{~g}$ of $\mathrm{DM} / \mathrm{d}$; and $\mathrm{HPHF}+=$ milk replacer with $27 \% \mathrm{CP}$ and $28 \%$ fat fed at $1431 \mathrm{~g}$ of $\mathrm{DM} / \mathrm{d}$.

${ }^{2} \mathrm{EBW}=$ empty body weight. 
Table 6. Manure excretion and DM digestibility in Holstein heifer calves fed milk replacers varying in protein and fat ${ }^{1}$

\begin{tabular}{|c|c|c|c|c|c|c|c|c|c|}
\hline \multirow[b]{3}{*}{ Item } & \multirow{2}{*}{\multicolumn{4}{|c|}{ Dietary treatment ${ }^{2}$}} & \multirow[b]{3}{*}{ SEM } & \multicolumn{4}{|c|}{$P<$} \\
\hline & & & & & & & $\mathrm{CON}$ & HPLF & HPHF \\
\hline & $\mathrm{CON}$ & HPLF & HPHF & $\mathrm{HPHF}+$ & & Treatment & vs. all & vs. HPHF & vs. HPHF+ \\
\hline Heifers, $n$ & 6 & 5 & 6 & 6 & & & & & \\
\hline DMI, kg/d & 1.41 & 1.53 & 1.45 & 1.76 & 0.16 & 0.32 & 0.33 & 0.71 & 0.13 \\
\hline DM digestibility,\% & 62.0 & 73.5 & 78.8 & 84.1 & 2.53 & 0.01 & 0.01 & 0.15 & 0.12 \\
\hline Feces DM, kg/d & 0.52 & 0.36 & 0.30 & 0.29 & 0.10 & 0.25 & 0.06 & 0.66 & 0.92 \\
\hline Urine, kg/d & 1.34 & 1.51 & 2.70 & 4.38 & 0.63 & 0.01 & 0.04 & 0.19 & 0.06 \\
\hline
\end{tabular}

${ }^{1}$ Data are from a 4 -d total collection period commencing on d 53 of study at $57 \pm 1 \mathrm{~d}$ of age.

${ }^{2} \mathrm{CON}=$ milk replacer with $20 \% \mathrm{CP}$ and $21 \%$ fat, fed at $441 \mathrm{~g}$ of DM/d; HPLF = milk replacer with $28 \%$ $\mathrm{CP}$ and $20 \%$ fat, fed at $951 \mathrm{~g}$ of DM/d; HPHF = milk replacer with $27 \% \mathrm{CP}$ and $28 \%$ fat, fed at $951 \mathrm{~g}$ of $\mathrm{DM} / \mathrm{d}$; and $\mathrm{HPHF}+=$ milk replacer with $27 \% \mathrm{CP}$ and $28 \%$ fat fed at $1,431 \mathrm{~g}$ of $\mathrm{DM} / \mathrm{d}$.

to have greater feces output $(0.52 \mathrm{vs} .0 .32 \mathrm{~kg}$ of DM/ $\mathrm{d} ; P<0.06)$ than other heifers due to greater starter consumption. Although water was available ad libitum, urine excretion was lowest in heifers fed CON (1.34 vs. $2.86 \mathrm{~kg} / \mathrm{d})$.

Total DMI, manure excretion, and DM digestibility were not influenced by the addition of fat (HPLF vs. HPHF). Feces excretion and DM digestibility were similar in HPHF + and HPHF, but urine output tended to be greater with $\mathrm{HPHF}+(4.38$ vs. $2.70 \mathrm{~kg} / \mathrm{d} ; P<0.06$; Table 6)

Nitrogen Balance. Total $\mathrm{N}$ intake was lowest in CON heifers because increased protein from high starter intake did not offset the low protein content of CON (Table 7). During the digestion study, fecal N excretion was not different, and $\mathrm{N}$ digestibility was lowest in heifers fed CON. Blome et al. (2003) reported a quadratic effect of dietary $\mathrm{CP}$ on fecal $\mathrm{N}$ excretion, with fecal $\mathrm{N}$ excretion increasing with $\mathrm{N}$ intake up to 29.4 $\mathrm{g}$ of $\mathrm{N} / \mathrm{d}$ and then declining when $\mathrm{N}$ intake reached 33.9 $\mathrm{g} / \mathrm{d}$. In contrast, our data set shows no effect of MR CP on fecal N, with MR varying from 20 to $28 \%$ protein. Ad libitum feeding of calf starter, in our study, made it difficult to separate effects of starter intake from those of MR intake. However, our results reflect the integrated responses of heifers under likely commercial conditions. Urinary N excretion was lower in CON than all other treatments (Table 7). Total $\mathrm{N}$ excretion was not different, but CON heifers retained less $\mathrm{N}$ than heifers that consumed the other diets (Table 7).

Increasing fat content of the high protein MR did not influence $\mathrm{N}$ intake, digestibility, excretion, or retention. Contrasting results were reported by Bascom et al. (2007) in a comparison of whole milk with MR of 21:21, 27:31, 29:16 (units are \% CP:\% fat) in Jersey calves. In that study, adding fat to the MR increased $\mathrm{N}$ retention. However, the calves were fed only a liquid diet, and digestibility was measured during the 5th week of life.

More $\mathrm{N}$ was supplied to heifers fed the HPHF+ than those fed HPHF, which was a goal of the treatment

Table 7. Nitrogen digestion and metabolism in Holstein calves fed milk replacers varying in protein and fat $^{1}$

\begin{tabular}{|c|c|c|c|c|c|c|c|c|c|}
\hline \multirow[b]{3}{*}{ Item } & \multirow{2}{*}{\multicolumn{4}{|c|}{ Dietary treatment ${ }^{2}$}} & \multirow[b]{3}{*}{ SEM } & \multicolumn{4}{|c|}{$P<$} \\
\hline & & & & & & \multirow[b]{2}{*}{ Treatment } & \multirow{2}{*}{$\begin{array}{c}\mathrm{CON} \\
\text { vs. all }\end{array}$} & \multirow{2}{*}{$\begin{array}{c}\text { HPLF } \\
\text { vs. HPHF }\end{array}$} & \multirow{2}{*}{$\begin{array}{c}\text { HPHF } \\
\text { vs. HPHF+ }\end{array}$} \\
\hline & $\mathrm{CON}$ & HPLF & $\mathrm{HPHF}$ & $\mathrm{HPHF}+$ & & & & & \\
\hline Heifers, $n$ & 6 & 5 & 6 & 6 & & & & & \\
\hline $\mathrm{N}$ intake, g/d & 44.2 & 60.8 & 56.4 & 71.6 & 5.30 & 0.02 & 0.01 & 0.55 & 0.04 \\
\hline Fecal N, g/d & 15.8 & 12.0 & 11.7 & 13.7 & 3.22 & 0.76 & 0.35 & 0.95 & 0.63 \\
\hline $\mathrm{N}$ digestibility,\% & 63.8 & 77.7 & 79.0 & 80.8 & 1.96 & 0.01 & 0.01 & 0.64 & 0.46 \\
\hline \multicolumn{10}{|l|}{ Urine $\mathrm{N}$} \\
\hline $\mathrm{g} / \mathrm{d}$ & 6.04 & 7.30 & 11.7 & 21.2 & 3.05 & 0.01 & 0.04 & 0.30 & 0.03 \\
\hline$\%$ of $\mathrm{N}$ intake & 19.1 & 12.6 & 19.9 & 30.0 & 7.56 & 0.40 & 0.83 & 0.49 & 0.30 \\
\hline Total $\mathrm{N}$ excretion, $\mathrm{g} / \mathrm{d}$ & 21.8 & 19.3 & 23.4 & 34.9 & 4.38 & 0.07 & 0.40 & 0.50 & 0.06 \\
\hline \multicolumn{10}{|l|}{$\mathrm{N}$ retention } \\
\hline $\mathrm{g} / \mathrm{d}$ & 22.4 & 39.6 & 33.0 & 36.6 & 5.94 & 0.18 & 0.04 & 0.42 & 0.63 \\
\hline$\%$ intake & 44.7 & 65.1 & 59.1 & 50.8 & 8.88 & 0.36 & 0.16 & 0.62 & 0.47 \\
\hline
\end{tabular}

${ }^{1}$ Data are from a 4-d total collection period commencing on d 53 of study at $57 \pm 1 \mathrm{~d}$ of age.

${ }^{2} \mathrm{CON}=$ milk replacer with $20 \% \mathrm{CP}$ and $21 \%$ fat, fed at $441 \mathrm{~g}$ of DM/d; HPLF $=$ milk replacer with $28 \%$ $\mathrm{CP}$ and $20 \%$ fat, fed at $951 \mathrm{~g}$ of $\mathrm{DM} / \mathrm{d}$; $\mathrm{HPHF}=$ milk replacer with $27 \% \mathrm{CP}$ and $28 \%$ fat, fed at $951 \mathrm{~g}$ of $\mathrm{DM} / \mathrm{d}$; and $\mathrm{HPHF}+=$ milk replacer with $27 \% \mathrm{CP}$ and $28 \%$ fat fed at $1,431 \mathrm{~g}$ of DM/d. 
Table 8. Phosphorus digestion and metabolism in Holstein heifer calves fed milk replacers varying in protein and fat ${ }^{1}$

\begin{tabular}{|c|c|c|c|c|c|c|c|c|c|}
\hline \multirow[b]{3}{*}{ Item } & \multirow{2}{*}{\multicolumn{4}{|c|}{ Dietary treatment ${ }^{2}$}} & \multirow[b]{3}{*}{ SEM } & \multicolumn{4}{|c|}{$P<$} \\
\hline & & & & & & \multirow[b]{2}{*}{ Treatment } & \multirow{2}{*}{$\begin{array}{c}\mathrm{CON} \\
\text { vs. all }\end{array}$} & \multirow{2}{*}{$\begin{array}{c}\text { HPLF } \\
\text { vs. HPHF }\end{array}$} & \multirow{2}{*}{$\begin{array}{c}\text { HPHF } \\
\text { vs. HPHF }\end{array}$} \\
\hline & $\mathrm{CON}$ & HPLF & HPHF & $\mathrm{HPHF}+$ & & & & & \\
\hline Heifers, $n$ & 6 & 5 & 6 & 6 & & & & & \\
\hline $\mathrm{P}$ intake, $\mathrm{g} / \mathrm{d}$ & 10.2 & 12.9 & 10.6 & 13.0 & 1.17 & 0.18 & 0.13 & 0.17 & 0.14 \\
\hline Fecal P, g/d & 4.00 & 2.41 & 2.30 & 3.56 & 1.11 & 0.59 & 0.31 & 0.94 & 0.39 \\
\hline $\mathrm{P}$ digestibility, $\%$ & 60.0 & 81.9 & 77.3 & 71.5 & 9.64 & 0.38 & 0.12 & 0.73 & 0.65 \\
\hline \multicolumn{10}{|l|}{ Urine $\mathrm{P}$} \\
\hline $\mathrm{g} / \mathrm{d}$ & 1.31 & 0.93 & 1.05 & 1.98 & 0.32 & 0.10 & 0.99 & 0.79 & 0.04 \\
\hline$\%$ intake & 16.6 & 7.48 & 10.2 & 15.7 & 4.97 & 0.48 & 0.32 & 0.70 & 0.40 \\
\hline Total P excretion, g/d & 5.31 & 3.34 & 3.35 & 5.54 & 1.13 & 0.31 & 0.32 & 1.00 & 0.15 \\
\hline \multicolumn{10}{|l|}{$\mathrm{P}$ retention } \\
\hline $\mathrm{g} / \mathrm{d}$ & 4.9 & 9.5 & 7.2 & 7.4 & 1.53 & 0.20 & 0.07 & 0.29 & 0.93 \\
\hline$\%$ intake & 43.4 & 74.4 & 67.1 & 55.8 & 11.5 & 0.24 & 0.09 & 0.65 & 0.46 \\
\hline
\end{tabular}

${ }^{1}$ Data are from a 4-d total collection period commencing at $57 \pm 1 \mathrm{~d}$ of age.

${ }^{2} \mathrm{CON}=$ milk replacer with $20 \% \mathrm{CP}$ and $21 \%$ fat, fed at $441 \mathrm{~g}$ of DM/d; HPLF $=$ milk replacer with $28 \%$ $\mathrm{CP}$ and $20 \%$ fat, fed at $951 \mathrm{~g}$ of DM/d; HPHF = milk replacer with $27 \% \mathrm{CP}$ and $28 \%$ fat, fed at $951 \mathrm{~g}$ of $\mathrm{DM} / \mathrm{d}$; and $\mathrm{HPHF}+=$ milk replacer with $27 \% \mathrm{CP}$ and $28 \%$ fat fed at $1,431 \mathrm{~g}$ of DM/d.

design (Table 7). Digestibility and fecal $\mathrm{N}$ excretion were unchanged, but urinary $\mathrm{N}$ nearly doubled $(21.2$ vs. $11.7 \mathrm{~g} / \mathrm{d} ; P<0.03)$ in heifers fed the greater volume of MR. Heifers fed the HPHF+ treatment consumed $15.2 \mathrm{~g} / \mathrm{d}$ more $\mathrm{N}$ than those fed HPHF, but $\mathrm{N}$ retention was unchanged because nearly all of the additional $\mathrm{N}$ was excreted in urine. Urinary $\mathrm{N}$ is typically more volatile than that excreted in feces (James et al., 1999), so greater partitioning of $\mathrm{N}$ to urine could have negative implications for air quality and odor emission.

Increased EBW protein content (Table 5) of heifers fed HPLF compared with those fed HPHF occurred despite the similar $\mathrm{N}$ retention (from digestibility study) in heifers fed the 2 treatments. Contrasting body protein composition data and observed $\mathrm{N}$ retention values are likely due to differences in the measurement period. Body protein changes reflect diet effects accrued across the 63-d study, whereas $\mathrm{N}$ retention results reflect changes in the final $4 \mathrm{~d}$ of the study.

Diaz et al. (2001) noted that when $\mathrm{N}$ retention was calculated from a digestibility trial rather than by body protein content at slaughter, $\mathrm{N}$ retained was overestimated by $27.5 \%$ using digestibility data. Possible losses of $\mathrm{N}$ in a digestibility trial include $\mathrm{N}$ loss in scurf, $\mathrm{N}$ loss due to splashing or evaporation, and due to loss of volatile $\mathrm{N}$ compounds in a drying oven (Blome et al. 2003). The current digestibility study overestimated $N$ retention by $8 \%$ when compared with slaughter data. The use of urinary catheters in the current study likely reduced loss of $\mathrm{N}$ due to splashing or evaporation, so the error in $\mathrm{N}$ retention decreased.

Phosphorus Balance. Phosphorus retention tended to be lower in heifers fed the CON diet compared with heifers fed more nutrient-dense diets (4.9 vs. 8.1 $\mathrm{g} / \mathrm{d} ; P<0.07$; Table 8). Phosphorus intake, digestion, excretion, and retention were unaffected by the addition of fat to the high protein diet. Phosphorus intake, digestibility, and fecal excretion were not different when the volume of HPHF MR was increased (HPHF+), but urinary $\mathrm{P}$ excretion increased with increased consumption. Interestingly, these young heifers excreted nearly as much urinary $\mathrm{P}(\sim 1$ to $2 \mathrm{~g} / \mathrm{d})$ as has been observed in lactating cows (Morse et al. 1992).

Manure Nutrient Excretion Compared with Mature Cows. In light of the recent changes in federal CAFO regulations to explicitly include stand-alone heifer and calf growing operations (EPA, 2003), it is interesting to compare manure nutrient excretion of preweaned heifers to that of mature cows. The EPA defines a large CAFO as one housing 700 mature dairy cows or 1,000 head of veal calves or other cattle. By comparing manure $\mathrm{DM}, \mathrm{N}$, and $\mathrm{P}$ excretion with predicted values for mature cows (ASAE, 2005), one can calculate the "cow equivalents" of 8- to 9-wk-old calves. According to our calculations it would take 16,950 calves (similar to those in this study) to produce the same quantity of manure solids as 700 mature lactating cows. A CAFO with 700 cows would produce approximately the same amount of $\mathrm{N}$ as 12,700 calves and the same amount of $\mathrm{P}$ as 12,450 calves. These equivalents were calculated using total excretion means across all treatment groups. On an equivalent nutrient or manure basis, the current CAFO cutoffs appear much more stringent for calf growers than for producers with lactating cows.

\section{CONCLUSIONS}

As others have observed, feeding more nutrientdense diets alters body composition, but adding fat to 
a high protein MR results in greater deposition of body fat without effect on protein gain or calf height and weight. Similarly, increasing feeding rate of a high protein and high fat MR increased protein and fat deposition without producing taller or longer heifers. Much of the additional nutrients consumed when heifers were fed HPHF+ were lost to the environment. Given the increased cost of nutrient dense MR, the lack of benefit in terms of stature or lean tissue gain, and the increased $\mathrm{N}$ excretion ( $\mathrm{HPHF}+)$ noted in this study, the use of HPHF or HPHF+ does not appear to be justified.

There is clear opportunity to improve calf growth and energy retention by feeding more nutrient-dense MR (Blome et al., 2003; Bartlett et al., 2006) and by feeding MR at a rate greater than "a pound of powder per day" (Bartlett et al., 2006). Additional work is needed to evaluate the effect of feeding a high protein and standard fat MR at a higher rate.

Data pertaining to the effects of MR composition and volume on feces, urine, and nutrient excretion are useful in light of changes in federal CAFO regulations. Although federal CAFO guidelines suggest that 1,000 calves are equivalent to 700 mature cows, we calculate that a calf grower would need to house 12,000 to 17,000 2-mo-old heifers to produce similar manure or manure nutrients as a 700-mature-cow CAFO.

\section{ACKNOWLEDGMENTS}

The authors thank Aaron Cornman, Michael Guard, Christopher Lily, and Shane Martin (Department of Dairy Science, Virginia Tech) for assistance feeding, weighing, and slaughtering heifers, and the staff at the abattoir at the Beltsville Agricultural Research Center (Beltsville, MD) for assistance with sample preparation. The financial assistance and donation of experimental and control MR by Land O'Lakes Inc. Animal Milk Products Co., Arden Hills, Minnesota, is greatly appreciated. The authors also thank APC Inc., Ames, Iowa, and Nouriche Nutrition Ltd., Lake St. Louis, Missouri, for supplying the Gammulin and electrolytes used in this study.

\section{REFERENCES}

Association of Official Analytical Chemists. 1984. Official Methods of Analysis. 14th ed. AOAC, Arlington VA.

Bartlett, K. S., F. K. McKeith, M. J. VandeHaar, G. E. Dahl, and J. K. Drackley. 2006. Growth and body composition of dairy calves fed milk replacers containing different amounts of protein at two feeding rates. J. Anim. Sci. 84:1454-1467.

Bascom, S., R. E. James, M. L. McGilliard, and M. E. Van Amburgh. 2007. Influence of dietary fat and protein on body composition of Jersey bull calves. J. Dairy Sci. 90:5600-5609.

Blome, R. M., J. K. Drackley, F. K. McKeith, M. F. Hutjens, and G. C. McCoy. 2003. Growth, nutrient utilization, and body composition of dairy calves fed milk replacers containing different amounts of protein. J. Anim. Sci. 81:1641-1655.

Daniels, K. M., S. R. Hill, K. F. Knowlton, R. E. James, M. L. McGilliard, and R. M. Akers. 2008. Effects of milk replacer composition on selected blood metabolites and hormones in pre-weaned Holstein heifers. J. Dairy Sci. 91:2628-2640.

Davis, C. L., and J. K. Drackley. 1998. The Development, Nutrition, and Management of the Young Calf. Iowa State University Press, Ames.

Diaz, M. C., M. E. Van Amburgh, J. M. Smith, J. M. Kelsey, and E. L. Hutten. 2001. Composition of growth of Holstein calves fed milk replacer from birth to 105-kilogram body weight. J. Dairy Sci. 84:830-842.

EPA. 2003. National Pollutant Discharge Elimination System Permit Regulation and Effluent Limitation Guidelines and Standards for Concentrated Animal Feeding Operations: Final Rule. 40 CFR Parts 122 and 412. Environmental Protection Agency, Washington, DC.

James, T., D. Meyer, E. Esparaza, E. J. DePeters, and H. PerezMonti. 1999. Effects of dietary nitrogen manipulation on ammonia volatilization from manure from Holstein heifers. J. Dairy Sci. 82:2430-2439.

Jaster, E. H., G. C. McCoy, and N. Spanski. 1992. Effect of extra energy as fat or milk replacer solids in diets of young dairy calves on growth during cold weather. J. Dairy Sci. 75:2524-2531.

Morse, D., H. H. Head, and C. J. Wilcox. 1992. Disappearance of phosphorus in phytate from concentrates in vitro and from rations fed to lactating dairy cows. J. Dairy Sci. 75:1979-1986.

National Research Council. 2001. Nutrient Requirements of Dairy Cattle. 7th rev. ed. Natl. Acad. Sci., Washington, DC.

SAS Institute. 1999. SAS Users Guide, Version 8.1. SAS Institute Inc., Cary, NC.

ASAE. 2005. D384.2 Manure Production and Characteristics. Am. Soc. Agric. Eng., St. Joseph, MI.

Tikofsky, J. N., M. E. Van Amburgh, and D. A. Ross. 2001. Effect of carbohydrate and fat content of milk replacer on body composition of Holstein bull calves. J. Anim. Sci. 79:2260-2267.

Tozer, P. R., and A. J. Heinrichs. 2001. What affects the costs of raising replacement dairy heifers: A multiple-component analysis. J. Dairy Sci. 84:1836-1844. 